\title{
EFFECTIVENESS OF BLACKBOARD AND EDMODO IN SELF-REGULATED LEARNING AND EDUCATIONAL SATISFACTION
}

\author{
Dr. Reem ALMOEATHER \\ ORCID: 0000-0001-7622-6514 \\ Faculty of Education \\ Princess Nourah Bint Abdulrahman University \\ Riyadh, SAUDI ARABIA
}

Received: 20/02/2019 Accepted: 24/04/2019

\begin{abstract}
Due to the increasing use of Internet-based Learning Management Systems (LMSs) and Social Learning Networks (SLNs), educators tend to employ these technologies in improving student learning skills and educational quality. This study investigates the impact of Blackboard LMS and Edmodo SLN on selfregulated learning and educational satisfaction among the Founding Year students at Princess Nourah Bint Abdulrahman University (PNU). The quasi-experimental approach applied to (148) students enrolled in the Founding Year, Faculty of Education, PNU. The participants were randomly distributed to two experimental groups: The first group compromised (61) students and the second one included (87) students.

For achieving the study objectives, Blackboard and Edmodo based learning environments were designed. The educational material was transformed into a digital educational content and uploaded on the Blackboard system. Furthermore, scales for self-regulated learning and educational satisfaction were prepared. The self-regulated learning scale composed of (9) items illustrating the contributions of e-learning systems for developing the students' self-regulated learning skills. The educational satisfaction scale comprised (8) items illustrating the satisfaction of the students with e-learning systems. After applying the two scales to the participants, a t-test was utilized to analyze data and calculate the significance of differences between the mean scores of the pre and posttests.
\end{abstract}

Results showed a statistically significant difference between the mean scores of the pre-and post-tests of selfregulated learning scale for Blackboard, favoring the post-test. There is a statistically significant difference between the mean scores of the pre-and post-tests of educational satisfaction scale for Blackboard, favoring the post-test. There is a statistically significant difference between the mean scores of the pre-and post-tests of self-regulated learning scale for Edmodo, favoring the post-test. There is a statistically significant difference between the mean scores of the pre-and post-tests of educational satisfaction scale for Edmodo, favoring the post-test. There is no statistically significant difference between the mean scores of the experimental group (taught using Blackboard) and the second experimental group (taught using Edmodo) in the post-test of the scale of self-regulation skills. There is no statistically significant difference between the mean scores of the experimental group (taught using Blackboard) and the second experimental group (taught using Edmodo) in the post-test of the scale of educational satisfaction. The study recommended holding training courses for students and faculty members on using Blackboard LMS and Edmodo SLN.

Keywords: Blackboard, Edmodo, educational satisfaction, learning management system, self-regulated learning, social learning network.

\section{INTRODUCTION}

The revolution in information and communication technology (ICT) has resulted in adapting technologies to create more effective learning environment. Learning Management Systems (LMSs) and Social Learning Networks (SLNs) become potentially useful tools employed to improve student learning skills and teaching quality. They are frequently adopted in university education as the instructor teaches the course including curriculum, tests, learning resources, and assignments using chat rooms, E-portfolio...etc. that support the 
courses (Aljerewy, 2010). As interactive educational applications, they are employed to develop a collaborative learning environment in which students can work together, exchange ideas and solve problems. Thus, LMSs and SLNs enhance student cognitive performance, learning skills and educational quality.

According to Alsalloum and Radwan (2013), Blackboard LMS performs three basic functions. It provides learning interaction tools while studying, including announcement, timing, tasks, grades, user manual, and notebook. It displays the content in various ways such as text with pictures, animation, documents and files, books and references, and important relevant links by clicking (course content). Further, it offers three ways of communication for learners with peers and instructors by sending and receiving e-mails, discussion boards, and virtual classrooms.

Edmodo SLN is a secure platform used in schools and universities to facilitate cooperation among students, peers, and instructors. Besides, it is easy to use and has a high level of acceptance by instructors. Therefore, it is an effective tool to create virtual classrooms without technical support (Kongchan, 2012).

Because learning is based on the learner and the activities that he/she carries out, it is necessary to focus on the learner's processes and skills in learning and acquiring knowledge, known as self-regulated learning. It is the processes in which students participate, intentionally plan, and exert behaviors motivated by the desire to employ cognitive, meta-cognitive, and emotionally defined learning skills and strategies to achieve academic objectives (Hassanein, 2011). Additionally, educational satisfaction is one of the most significant success indicators of the learning environment. Universities shall be more responsive to student's educational stratification indicators. It is defined as the total of behavioral beliefs and attitudes of the learner resulting from the collection of all advantages and benefits received from employing a specific learning model (O'Leary and Quinlan, 2007).

The present study selects two widely utilized tools, namely Blackboard and Edmodo, to investigate their impact on the Founding Year student self-regulated learning and educational satisfaction.

\section{CONCEPTUAL FRAMEWORK AND LITERATURE REVIEW}

\section{Blackboard LMS}

Blackboard is a commercial learning management system that was created by Blackboard Inc. It was designed on educational bases that help instructors provide an e-learning environment. It can be offered at the individual or university levels. It provides more than a hundred templates and supports word and PDF files for E-publishing. It also offers an interactive system for saving and retrieval of student scores, as well as test samples created by the instructor (Abdulatty, 2015).

Badawy (2011) and Alnajjar (2010) argue that Blackboard has many advantages such as discussion forums, uploading and sharing files, helping disseminate online learning, supporting audio, video, and text, supporting student self-learning and creating self-tests for learners, either with or without timing. It is also characterized by flexibility in accessing the system anywhere and anytime, facilitating the access of the instructor who can create an account to design the electronic course; provide course settings regarding form, shape, title, and start time and organize the course. Blackboard is compatible with international standards such as Sharable Content Object Referent Model (SCORM) and Integrated Management System (IMS).

It is an effective LMS as it motivates creativity and activates the mind, thinking, and opinion expression. It has achieved the best results in terms of its sharing components and items that triggered the development of achievement and skill aspects of the educational process (Craf and List, 2005).

Thus, many studies reported the effectiveness of Blackboard in the educational process, including Sawaftah (2016), AlShaya and AlHidari (2015), Al-Sadhan (2015), Aljarrah (2012), Heirdsfield, Walker, Tambyah, and Beutel (2011), and Martin (2008). The Supreme Council for Higher Education in Saudi Arabia applied Blackboard at all national universities because of its high effectiveness, security, privacy, and continuous development (Abdulwahab, 2016). 


\section{Edmodo SLN}

Edmodo is a social learning network that has attracted a large number of users, i.e., about 77 million instructors and students worldwide, since its creation in 2008. It is free, relatively secure, and easily enhance contact and cooperation among students in the classroom, school, or schools. It offers many learning tools such as discussion, group organization, running competitions, and receiving instant feedback (Almatrody and Alhassan, 2017).

According to Jalal and Zaidieh (2012), Beverley (2012) and Grosseck and Holotescu (2010), Edmodo has many advantages. First of all, it is a free service, easy to use and provides educational models that respond to the different learning needs of students. It integrates social networking interface with learning tools to enable instructors, students, guardians, and administrators to communicate and interact in the educational issues in a safe manner. It helps to overcome the challenges of using traditional social media such as Facebook and MySpace in education, including privacy and security. Edmodo thus represents a virtual digital repository of learning data and resources that the instructors want to share.

Because of its importance, many studies reported the effectiveness of Edmodo as a SLN, such as Alzahrany and Mejlad (2018), Almoqren (2016), Thongmak (2013), Sanders (2012), Beverley (2012), Schachter (2011), Kongchan (2012), and Grosseck and Holotescu (2010). According to the American Library Association (2011), Edmodo is one of the best (25) websites for teaching and learning that promote creativity, innovation, active participation, and collaboration under the category of "social communication and networking".

\section{Self-Regulated Learning}

Bandura (2002) reported self-regulation among learners as a part of the social cognitive theory. He believes that learning is a social process that takes place in a certain frame of social relations between the student and himself/ herself, the student and instructor, and the student and peers. Thus, learners can adjust their behaviors via conceptions and beliefs on the implications, and that self-regulation helps make changes to behavior. These skills have three essential components: The strategies including objective and means, self-feedback, and recognizing the importance of work and preparation. They cause developed training processes and high efficiency (Aljarrah, 2010). Furthermore, Schunk and Zimmerman (2007) and Cleary and Zimmerman (2004) report that the development of self-regulation has four levels, namely observation, emulation, self-control, and self-regulation.

According to Alhaqbany (2017) and Abdulhameed (2011), self-regulated student shows more awareness of the assumed responsibility, perceives the educational problems as challenges, has motivation, perseverance, self-control, self-discipline, and trust. Self-regulated student also participates actively in the learning process and responds to the different educational situations and employs effective methods to process the information obtained in learning by generating ideas that help guide the knowledge and skills. Self-regulated learning behaviors help achieve the aspired educational objectives. Vrugt and Oort (2008) reported self-regulation as one of the educational objectives that improve the active learning process.

Many studies addressed self-regulation in e-learning environments, e.g., Sayed (2017), Cigdem (2015), Duru, Duru, and Balkis (2014), Bernacki, Byrnes and Cromley (2012) and Abdulhameed (2011).

Sansone, Fraughton, Zachany, Butner, and Heiner (2011) argue that self-regulated learning can be developed based on the integration of some e-learning strategies that provide follow-up of the student's performance, feedback, support, or direct classroom support among all parties involved in learning.

\section{Educational Satisfaction}

Moore (2009) illustrates that educational satisfaction comprises five major domains, i.e. Discussion and interaction with instructors and peers; Actual learning experiences match expectations; services (advising, registration, access to materials) is at least as good as on the traditional campus; Orientation for how to learn online is satisfactory; and Outcomes are useful for career, professional, and academic development. Because of the importance of educational satisfaction as an indicator of the success of the learning process, many 
studies investigated the effectiveness of some e-learning systems in achieving educational satisfaction among students such as Zhonggen and Guifang (2016); Chen, Wang, Kinshuk, \& Chen (2014); Aljarrah (2012); Seyal et al. (2010).

Furthermore, Aljanzoury (2017), Al-Sadhan (2015), Mazrou, Abdulrahman, and Makhlouf (2013), Aljarrah (2012), and Heirdsfield et al. (2011) tackled the attitudes of learners and faculty members at the universities towards the Blackboard system. Mohamed (2017), Al-Kathiri (2015), and Al-Said (2015) investigated the students' attitudes towards the Edmodo system. However, no previous study has addressed the impact of Blackboard and Edmodo on self-regulated learning and educational satisfaction. Accordingly, the present research seeks to investigate the impact of utilizing the Blackboard and Edmodo on developing the skills of self-regulation and educational satisfaction among the Founding Year students at PNU.

\section{Questions}

1. What is the impact of Blackboard on self-regulated learning among the Founding Year students at PNU?

2. What is the impact of Blackboard on educational satisfaction among the Founding Year students at PNU?

3. What is the impact of Edmodo on self-regulated learning among the Founding Year students at PNU?

4. What is the impact of Edmodo on educational satisfaction among the Founding Year students at PNU?

5. What is the difference between the impact of Blackboard and Edmodo on self-regulated learning among the Founding Year students at PNU?

6. What is the difference between the impact of Blackboard and Edmodo on educational satisfaction among the Founding Year students at PNU?

\section{Hypotheses}

1. There is a statistically significant difference between the mean scores of the pre-and post-tests of selfregulated learning scale for Blackboard, favoring the post-test.

2. There is a statistically significant difference between the mean scores of the pre-and post-tests of educational satisfaction scale for Blackboard, favoring the post-test.

3. There is a statistically significant difference between the mean scores of the pre-and post-tests of selfregulated learning scale for Edmodo, favoring the post-test.

4. There is a statistically significant difference between the mean scores of the pre-and post-tests of educational satisfaction scale for Edmodo, favoring the post-test.

5. There is no statistically significant difference between the mean scores of the experimental group (taught using Blackboard) and the second experimental group (taught using Edmodo) in the post-test of the scale of self-regulation skills.

6. There is no statistically significant difference between the mean scores of the experimental group (taught using Blackboard) and the second experimental group (taught using Edmodo) in the post-test of the scale of educational satisfaction.

\section{METHODOLOGY}

The research adopted the quasi-experimental approach to evaluate the effectiveness of Blackboard LMS and Edmodo SLN in self-regulated learning and educational satisfaction among the Founding Year students at PNU. Two groups were selected; the first experimental group taught using Blackboard and the second experimental one taught using Edmodo. The scales of self-regulated learning and educational satisfaction were pre-tested and post-tested to the groups. 


\section{Population \& Sampling}

\section{Population}

The research covered all the Founding Year students at the College of Education, PNU, numbered (365) in the second semester of 2017/2018.

\section{Sample}

The Founding Year students at the College of Education, PNU enrolled in e-learning course in the second semester of 2017/2018 numbered (148). They were distributed randomly to two experimental groups: the first experimental group consisted of (61) students and the second experimental group consisted of (87) ones.

Tools

1. self-regulated learning scale

It measures the university students' self-regulation skills. It comprises (9) items illustrating the contributions of e-learning systems for developing the students' self-regulated learning skills.

\section{Validity}

a. Reviewer validity

The author submitted the scale's items to six reviewers of the faculty members at the Departments of Curriculum and Instruction and Psychology at some Saudi universities to survey their opinions on the appropriateness and wording of the items. All notes were considered. The reviewers agreed on $(90 \%)$ of the items. They mostly agreed on the validity and reliability of the scale.

b. Internal validity

The author applied the scale to a pilot sample of (50) students in the Founding Year at the College of Education, PNU in the second semester of 2017/2018 to calculate Pearson Correlation Coefficients between each item and the total score of the scale.

Table 1. Correlation Coefficients between each item and the total score of the scale $(\mathrm{N}=50)$

\begin{tabular}{|c|c|c|}
\hline \multicolumn{3}{|c|}{ Self-regulation skills } \\
\hline No. & Item & Correlation coefficient \\
\hline 1 & It offered limited potentials to develop my progress evaluation skills in the course. & $.519\left(^{* *}\right)$ \\
\hline 2 & It helped develop my skills to link my previous and current knowledge. & $.740\left(^{* *}\right)$ \\
\hline 3 & $\begin{array}{l}\text { It offered a new environment to organize my time and effort and to distribute them } \\
\text { to the learning tasks. }\end{array}$ & $.701\left(^{* *}\right)$ \\
\hline 4 & $\begin{array}{l}\text { It provided technological means that provide an opportunity to develop self- } \\
\text { control. }\end{array}$ & $.512(* *)$ \\
\hline 5 & $\begin{array}{l}\text { It helped develop the skills of searching for the information that enhances my } \\
\text { understanding of the course topic. }\end{array}$ & $.661\left(^{* *}\right)$ \\
\hline 6 & It helped focus and adjust learning via the e-learning system. & $.772\left({ }^{* *}\right)$ \\
\hline 7 & It enabled me to define my learning objectives. & $\left..7311^{* *}\right)$ \\
\hline 8 & It helped schedule my tasks and set my priorities. & $.711(* *)$ \\
\hline 9 & It helped me to organize my ideas logically and coherently display. & $.742(* *)$ \\
\hline
\end{tabular}

**ignificant at the level of $(0.01)$

Table 1. shows that the values of the correlation coefficients were in the closed interval [0.512-0.772]. Thus, they are statistically significant at the level of 0.01 , suggesting the validity of the items. 


\section{Reliability}

The scale reliability estimated using Cronbach's alpha. It equaled [0.852], suggesting the high reliability of the scale.

2. Educational satisfaction scale

It measures the educational satisfaction of university students. It comprises (8) items illustrating the satisfaction of the students with e-learning systems.

\section{Validity}

a. Reviewer validity

The scale's items submitted to six reviewers of the faculty at the Departments of Curriculum and Instruction and Psychology at some Saudi universities to survey their opinions on the appropriateness and wording of the items. All notes were considered. The reviewers agreed on (85\%) of the items. They mostly agreed on the validity and reliability on the scale to measure the educational satisfaction with learning management systems.

b. Internal validity

The scale applied to the same pilot sample to calculate Pearson Correlation Coefficients between each item and the total score of the scale.

Table 2. Correlation Coefficients between each item and the total score of the scale $(\mathrm{N}=50)$

\begin{tabular}{clc}
\hline Educational satisfaction & \multicolumn{1}{c}{ Item } & $\begin{array}{c}\text { Correlation } \\
\text { coefficient }\end{array}$ \\
\hline No. & $\begin{array}{l}\text { I think that the Edmodo/ Blackboard system enabled me to learn and consider copyrights } \\
\text { in a more practical manner. }\end{array}$ & $.524\left(^{* *}\right)$ \\
2 & $\begin{array}{l}\text { Learning via the Edmodo/ Blackboard system helped me take a firm stand towards the } \\
\text { legal frameworks, rules, and regulations regulating handling the digital content. }\end{array}$ & $.500\left(^{* *}\right)$ \\
3 & $\begin{array}{l}\text { I think that it is acceptable to share the digital content via the Edmodo system without } \\
\text { citation. }\end{array}$ & $\left..528^{* *}\right)$ \\
4 & $\begin{array}{l}\text { I think that the Edmodo/ Blackboard system is open-sourced. Thus, there is no need to } \\
\text { punish the student who cites digital content without reference. }\end{array}$ & $.526\left(^{* *}\right)$ \\
5 & $\begin{array}{l}\text { I act independently and assume responsibility for my behavior and choices when creating } \\
\text { digital content via the Edmodo system. }\end{array}$ & $.516\left(^{* *}\right)$ \\
6 & $\begin{array}{l}\text { I think that I understood creative commons in a good manner via discussion and offering } \\
\text { Infographic project via the Edmodo system. }\end{array}$ & $.470\left(^{* *}\right)$ \\
7 & $\begin{array}{l}\text { I believe that creative commons are not a good solution to handle the copyrights of the } \\
\text { digital content via the Edmodo system. }\end{array}$ & $.522\left(^{* *}\right)$ \\
8 & I believe that the Edmodo/ Blackboard system helps plagiarize others'ideas with impunity. & $\left..6122^{* *}\right)$ \\
\hline
\end{tabular}

**ignificant at the level of (0.01)

Table 2. shows that the values of the correlation coefficients were in the closed interval [0.470-0.612]. Thus, they are statistically significant at the level of 0.01 , suggesting the validity of the items.

\section{Reliability}

The reliability of the scale was estimated using Cronbach's alpha. It equaled [0.620], suggesting the high reliability of the scale.

3. Transforming the educational material into digital content and uploading it the Blackboard system The model of Abdelmonem and Naem (2000) comprising six stages was adopted. The following section shows these stages and procedures. 
A. Study and analysis

1. Identify the area of interest: an E-learning course was selected for the Founding Year students at PNU.

2. Selecting the appropriate educational content: the content of the E-learning course was selected as multiple items available online can be employed, including audio, text, pictures, static and animated drawings, and video clips.

3. Utilization of the interactive media: The multimedia and tools that enhance the learner's interaction with the educational situations were defined.

4. Setting utilization requirements: The pre-test requirements were defined to be considered when preparing the educational content, including learners' characteristics: Learners' characteristics, learner's behavior towards the learning approach and learning style.

B. Educational design:

1. Dividing the content into modules.

2. Setting educational objectives.

3. Analyzing the module content and selecting the appropriate educational means, including multimedia, links to enrichment websites, evaluation tools, and social communication tools.

4. Describing the learning environment: The environment is self-learning, where the student learns the digital content via the electronic means that are self-paced according to abilities.

C. Interaction design

1. Defining the types, styles, and levels of interaction for educational tasks such as setting the interaction styles that allow the student to display the digital educational content in sequence or network form simultaneously and defining the interaction levels. It includes the level of reception and watching, controlling the display sequence, watching level and answering questions, receiving feedback, watching level and response to the chat rooms.

2. Designing the interfaces (screens): The pages of the educational content were designed while pitting into consideration attracting student attention and offered an interactive environment: appropriate background, font sizes, amount of information, using colors and fixed and animated drawings, line spaces, as well as interaction types, methods, and levels. Additionally, it was planned to enrich the screens with links to YouTube video clips and links to enrichment websites on the Internet.

3. Preparing the storyboard and preliminary scenario: In this stage, the broad lines of the educational content were turned into detailed procedures on paper. A road map was made to display the scenes of each module, including multimedia, interaction patterns, links to videoclips, links to enrichment websites, and content of the screens using a scenario that has the text, pictures, drawings, video clips, and links.

D. Production

In this stage, the scenario was transformed into an educational program using the course tools of the Blackboard and Edmodo systems to create two educational settings on two different environments with the same educational content.

E. Review and testing

1. Alpha test: The preliminary model of the program was displayed to a group of experts in the curriculum and instruction of educational technology. Their proposed modifications were made.

2. Beta test: The two programs were applied to (11) students of the population, but not from the sample. They were asked to take notes, and some modifications were made based on them.

F. Application:

In this stage, social networking tools including chat rooms, assignment upload tool, and links to interactive enrichment websites were added. The faculty member applied them to the participants inside and outside the lecture to display the content. Each student could study the content online after logging to the Blackboard or Edmodo system. 
While designing the learning management systems, the author considers the following:

1. Self-management of thinking: Appropriate objectives were set to trigger a challenge, effective planning, and self-control. The student identifies what she knows or does not know to distinguish the self-understanding of the topic. Additionally, she reviews self-learning while committing to highperformance standards.

2. Activating all students: Appropriate objectives were set to trigger a challenge in the form of real problems to be resolved by the student. That is, the student does not rely on the instructor as the main source of information, nor one minor group of students. Instead, resolving the problem depends on all students.

3. Designing easy and clear interfaces in the learning environments to achieve collaborative learning, using appropriate programs, setting the timeline of task achievement from one to six days according to the task. The collaborative groups were set to five students. Evaluating the quality of collaboration within and between the groups was planned to be guided and supervised by the instructors.

4. Regulating collaborative learning in three stages. It starts with generating the idea by capturing knowledge from the various learning resources; generating the idea according to understanding, culture, and structure; displaying it to the group members. In the stage of idea organization, the group members discuss the ideas to choose the best. In the stage of cognitive interconnectedness, one connected idea is generated representing the group members leading to applying the acquired knowledge.

5. Self-regulation:

It can be in the form of many methods in e-learning environments, including direct instruction, reflective thinking, discussion, and discussion with the instructor synchronically and diachronically.

6. Periodic measurement and self-evaluation of the learning processes:

It helps follow-up on the progress of goal achievement leading to a deeper and more accurate understanding of learning by analyzing the student's learning styles and comparing them to those of the peers in the group or other groups supervised by the instructors to raise self-awareness of the learning methods.

\section{RESULTS AND DISCUSSION}

1. To answer the first question and verify the first hypothesis, a t-test was used to calculate the significance of the difference between the mean scores of the pre-and post-tests of self-regulation scale.

Table 3. Differences of the mean scores of the pre-and post-tests of self-regulation scale

\begin{tabular}{|c|c|c|c|c|c|c|c|}
\hline Group & Number & Means & $\begin{array}{l}\text { Standard } \\
\text { deviation }\end{array}$ & T-Value & Significance level & $\eta 2$ & Effect size \\
\hline Pre-test & 61 & 12.26 & 1.34 & 11.46 & Significant & 0.93 & High \\
\hline Post-test & 61 & 40.67 & 1.45 & & & & \\
\hline
\end{tabular}

Table 3. shows that there are differences between the mean scores of the pre-and post-tests of self-regulation scale. Thus, the first hypothesis is verified. That is, there are differences between the mean scores of the preand post-tests of self-regulation scale for Blackboard, favoring the post-test. The effect size of the independent variable (Blackboard) on the dependent one (self-regulation skills) was high, suggesting the effectiveness of Blackboard in developing self-regulation skills among the Founding Year students at PNU. Consequently, the first question is answered.

This result is obtained because "Blackboard" puts the student into an interactive learning environment that is rich in boosters, making her the center of the educational process. This supports what was taught in the lecture when the student logs into the system and restudies the educational content according to her abilities 
and self-speed. She communicates, asks questions, and receives answers with peers and instructors via available social media such as e-mail and discussion boards. Thus, she is motivated to develop self-regulation skills. The "Blackboard" makes a student-centered educational process through search and resolving the problems in the tasks. The system helps the student study the educational content outside the classroom, including doing more exercises and assignments, watching video clips on Youtube, and longing into relevant enrichment websites. It gives the faculty member the opportunity to follow-up the performance of the first experimental group and doing assignments, to evaluate learning, and to provide the appropriate feedback. This dramatically enhances academic achievement and self-regulation skills.

To sum up, the Blackboard system and its educational activities helped students to overcome their wrong self-conception as well as to pay attention to their inner thoughts of hope, reassurance and optimism. It also increased their awareness of their abilities, their motivation to improve, and their ability to deal with study problems effectively. It shows that the Blackboard system has met their need to develop self-regulation skills.

This result matches Sayed (2017), Sawaftah (2016), AlShaya and AlHidari (2015), Al-Sadhan (2015), Cigdem (2015), Duru et al. (2014), Aljarrah (2012), Bernacki et al. (2012), Heirdsfield et al. (2011), and Sansone et al. (2011) in terms of the advantages and effectiveness of Blackboard.

2. To answer the second question and verify the second hypothesis, a t-test was used to calculate the significance of the difference between the means of scores of the pre-and post-tests of educational satisfaction scale.

Table 4. Differences of the mean scores of the pre-and post-tests of the educational satisfaction scale

\begin{tabular}{|c|c|c|c|c|c|c|c|}
\hline Group & Number & Means & $\begin{array}{l}\text { Standard } \\
\text { deviation }\end{array}$ & T-Value & Significance level & $\eta 2$ & Effect size \\
\hline Pre-test & 61 & 12.76 & 2.71 & 14.31 & Significant & 0.94 & High \\
\hline Post-test & 61 & 36.84 & 3.16 & & & & \\
\hline
\end{tabular}

Table 4. shows that there are statistical differences between the mean scores of the pre-and post-tests for educational satisfaction scale. Thus, the second hypothesis is verified. That is, there are statistical differences between the mean scores of the pre-and post-tests of educational satisfaction scale for Blackboard, favoring the post-test. The effect size of the independent variable (Blackboard system) on the dependent one (educational satisfaction) was high, suggesting the effectiveness of Blackboard in developing educational satisfaction among the Founding Year students at PNU. As a result, the second question is answered.

This result is obtained because "Blackboard" system allows the students adequate time to practice the enrichment and discovery activities. That is, it concentrates on the positive participation of the student in learning, enhancing learning motivation and having positive attitudes towards the system and interest in it. It offers the students extra learning resources related to the course and individual learning environments. It causes effective integration of the learning resources, making learning more fun. It enables faculty members to organize the material continuously. It helps the student learn without committing to place or time, and enhances the student's understanding.

To conclude, The Blackboard system allows direct contact between the student and the teacher and between the students and each other. Thus, it helps improve students' skills of using modern technology and communication and searching for information and knowledge. Therefore and unlike the traditional approach, the student becomes at the center of the educational process, which raises students' satisfaction with the educational process. These features of the Blackboard system led to the increase of students' satisfaction with the educational process.

This result matches the results of Aljanzoury (2017), Sawaftah (2016), AlShaya and AlHidari (2015), Al-Sadhan (2015), Mazrou et al. (2013), Aljarrah (2012), and Heirdsfield et al. (2011), in terms of the advantages and effectiveness of Blackboard.

3. To answer the third question and verify the third hypothesis, a t-test was used to calculate the significance of the difference between the means of scores of the pre-and post-tests of self-regulation scale. 
Table 5. Differences of the mean scores of the pre-and post-tests of self-regulation scale

\begin{tabular}{cccccccc}
\hline Group & Number & Means & $\begin{array}{c}\text { Standard } \\
\text { deviation }\end{array}$ & T-Value & Significance level & n2 & Effect size \\
\hline Pre-test & 87 & 12.96 & 2.67 & 10.94 & Significant & 0.90 & High \\
\cline { 1 - 5 } Post-test & 87 & 40.72 & 5.93 & & & & \\
\hline
\end{tabular}

Table 5. shows that there are differences between the mean scores of the pre-and post-tests for self-regulation scale. Thus, the third hypothesis is verified. That is, there are statistical differences between the mean scores of the pre-and post-tests of self-regulation scale for the Edmodo system, favoring the post-test. The effect size of the independent variable (Edmodo system) on the dependent one (self-regulation skills) was high, suggesting the effectiveness of Edmodo in developing self-regulation skills among the Founding Year students at PNU. As a result, the third question is answered.

This result is attributed to the positive results of utilizing Edmodo in teaching as the systems provide the students with potentials to fulfill the learning goals and tasks that require self-regulated learning strategies. Consequently, the student becomes the center of the educational process through research and solving problems of the educational tasks. The student does not rely on the instructor as a source of information, nor a group of students. Instead, these systems depend on activating the cognitive and skillful abilities of all students with the instructor's guidance. Besides, Edmodo helps the student overcome the educational situation regardless of difficulty or easiness. It helps the students compare their abilities and readiness to their peers. Based on what it offers of learning resources that are varied and not restricted to place or time, Edmodo enables the students to contact instructors and peers and post questions in private or public, improving achievement and self-regulation skills. It offers educational material, activities, and evaluation methods in a way that helps model work and achievement and develop self-regulation skills.

Edmodo and its techniques, exercises and educational skills helped the students develop scheduled study plans based on clear goals and objectives. It also increased their ability to manage time and energy and improved their skills of taking responsibility. Accordingly, they become more able to improve performance and replace negative habits with positive ones.

This result matches the results of Alzahrany and Mejlad (2018), Mohamed (2017), Almoqren (2016), Thongmak (2013), Sanders (2012), Beverley (2012), Schachter (2011), Kongchan (2012), and Grosseck and Holotescu (2010) regarding the advantages and effectiveness of Edmodo.

4. To answer the fourth question and verify the fourth hypothesis, a t-test was used to calculate the significance of the difference between the means of scores of the pre-and post-tests of educational satisfaction scale.

Table 6. Differences of the mean scores of the pre-and post-tests of the educational satisfaction scale

\begin{tabular}{|c|c|c|c|c|c|c|c|}
\hline Group & Number & Means & $\begin{array}{l}\text { Standard } \\
\text { deviation }\end{array}$ & T-Value & Significance level & $\eta^{2}$ & Effect size \\
\hline Pre-test & 87 & 10.32 & 1.63 & 12.46 & Significant & 0.95 & High \\
\hline Post-test & 87 & 43.20 & 3.32 & & & & \\
\hline
\end{tabular}

Table 6. shows that there are differences between the mean scores of the pre-and post-tests of educational satisfaction scale. Thus, the fourth hypothesis is verified. That is, there are statistical differences between the mean scores of the pre-and post-tests of educational satisfaction scale for Edmodo, favoring the post-test. The effect size of the independent variable (Edmodo system) on the dependent one (educational satisfaction) was high, suggesting the effectiveness of utilizing Edmodo system in teaching e-learning course on developing educational satisfaction among the Founding Year students at PNU. As a result, the fourth question is answered. 
This result is attributed to the positive results of utilizing Edmodo in teaching since the students utilize Edmodo in sharing the experience with peers and in solving shared assignments. It also motivates collaborative learning and saves time and overcomes boredom. Displaying the educational material via Edmodo triggers students' interest as it enhances interaction, communication, problem-solving, as well as communication with the faculty members. Furthermore, Edmodo is familiar for most of the students regarding external design and colors. It saves the time of the lecture and overcome boredom as it affords the option of contact at any time and place. This was reflected in the easy use and high level of achievement, as it allows having immediate feedback by the faculty as well as the other students. All these features have led to increasing students' educational satisfaction.

This result matches the results of Mohamed (2017), Al-Said (2015), and Al-Kathiri (2015) regarding the advantages and effectiveness of Edmodo.

5. To answer the fifth question and verify the fifth hypothesis, t-test was used to calculate the significance the difference between the means of scores of the first and second experimental groups in the post-test of self-regulation scale.

Table 7. Differences of the mean scores of the first and second experimental groups in the post-test of selfregulation scale

\begin{tabular}{ccccccc}
\hline Group & Number & Means & $\begin{array}{c}\text { Standard } \\
\text { deviation }\end{array}$ & T-Value & Significance level & T-Significance \\
\hline $\begin{array}{c}\text { First } \\
\text { Experimental }\end{array}$ & 61 & 33.33 & 5.668 & -.503 & .616 & Insignificant \\
$\begin{array}{c}\text { Second } \\
\text { Experimental }\end{array}$ & 87 & 33.79 & 5.441 & & & \\
\hline
\end{tabular}

Table 7. shows there is no statistically significant difference between the mean scores of the first and second experimental groups in the post-test of self-regulation scale. Thus, the fifth hypothesis is verified. There are no statistical differences between the students taught using Blackboard and those taught using Edmodo in developing their self-regulation.

This result is attributed to the positive effects of utilizing Blackboard and Edmodo in teaching as the student assumes responsibility for learning through assignments and tasks done while teaching individually or collaboratively, helping evaluate learning continually. The various resources for obtaining information on the course. Additionally, linking the information to former experience helps employ external reading to improve the students' level. These systems motivate the students to participate and interact, improving self-dependence. Thus, learning becomes easier, and monitoring and control of the learning environment improve. The systems provide the students with potentials to fulfill the learning goals and tasks that require self-regulated learning strategies.

Consequently, the student is the center of the educational process through research and solving problems of the educational tasks. The student does not rely on the instructor as a source of information, nor a group of students. Instead, these systems depend on activating the cognitive and skillful abilities of all students with the instructor's guidance. This result matches the results of Sayed (2017), Sawaftah (2016), AlShaya and AlHidari (2015), Al-Sadhan (2015), Cigdem (2015), Duru et al. (2014), Aljarrah (2012), Bernacki et al. (2012), Heirdsfield et al. (2011), and Sansone et al. (2011) in terms of the advantages and effectiveness of Blackboard. It also matches the results of Alzahrany and Mejlad (2018), Mohamed (2017), Almoqren (2016), Thongmak (2013), Sanders (2012), Beverley (2012), Schachter (2011), Kongchan (2012), and Grosseck and Holotescu (2010) regarding the advantages and effectiveness of Edmodo.

6. To answer the sixth question and verify the sixth hypothesis, a t-test was used to calculate the significance the difference between the means of scores of the first and second experimental groups in the post-test of educational satisfaction scale. 
Table 8. Differences of the mean scores of the first and second experimental groups in the post-test of the educational satisfaction scale

\begin{tabular}{ccccccc}
\hline Group & Number & Means & $\begin{array}{c}\text { Standard } \\
\text { deviation }\end{array}$ & T-Value & Significance level & T-Significance \\
\hline $\begin{array}{c}\text { First } \\
\text { Experimental }\end{array}$ & 61 & 28.39 & 4.424 & 0.019 & 0.985 & Insignificant \\
\cline { 2 - 4 } $\begin{array}{c}\text { Second } \\
\text { Experimental }\end{array}$ & 87 & 28.38 & 4.284 & & & \\
\hline
\end{tabular}

Table 8. shows that there are no statistically significant differences between the mean scores of the first and second experimental groups in the post-test of educational satisfaction scale. Thus, the sixth hypothesis is verified.

This result is obtained because Blackboard and Edmodo are characterized by involving the student into an interactive learning environment that is rich in boosters and creating a student-centered educational process. This supports what was taught in the lecture when the student logs into the system and restudies the educational content according to her abilities and self-speed. Watching video clips on YouTube and longing into enrichment websites on the Internet help offer interactive educational material. Consequently, the student interacts with educational situations and experiences, and one is motivated to study the content outside the classroom, to practice more exercises, and to do assignments. Also, these systems are easy to learn, as they do not require a specialist. They are easily accessible from anywhere such as the house or university. They help the student do tasks easily and effectively and offers a variety of student evaluation methods. They are also characterized by contribution to developing the course content, a variety of courserelated assignments and activities, enhancing student's understanding, educational efficiency, and use of technological results and roles. In turn, they all help to enhance the student's beliefs, aspirations, abilities, and achievement. Thus, the student enjoys learning and achievement, lowering fears and anxiety, improving self-trust and self-satisfaction, and forming positive attitudes.

This result matches Aljanzoury (2017), Sawaftah (2016), AlShaya and AlHidari (2015), Al-Sadhan (2015), Mazrou et al. (2013), Aljarrah (2012), and Heirdsfield et al. (2011), in terms of the advantages and effectiveness of Blackboard. It also matches Mohamed (2017), Al-Said (2015), and Al-Kathiri (2015) regarding the advantages and effectiveness of Edmodo.

\section{RECOMMENDATIONS}

The research recommends:

1. Holding training courses to train students and faculty members at the Saudi universities on utilizing Blackboard and Edmodo as models of learning management systems.

2. Training the faculty members on transforming courses into digital forms and uploading them to a learning management system, such as Blackboard.

3. Motivating the faculty members to employ educational networks, e.g., Edmodo, to teach many courses.

4. Holding workshops, training courses, and awareness-raising campaigns by the faculty members to educate the students on the importance of self-regulation and its impact on their academic and nonacademic performances.

Acknowledgment: This Research was funded by the Deanship of Scientific Research at Princess Nourah bint Abdulrahman University through the fast-track Research Funding Program. 


\section{BIODATA and CONTACT ADDRESSES of AUTHOR}

Dr. Reem A. ALMOEATHER, is an Associate Professor of Educational Technology, Faculty of Education, Princess Nourah bint Abdulrahman University, Riyadh.Saudi Arabia. She is responsible for the Training of Trainers (TOT). She is also director of Higher Diploma Program in E-Learning.

Reem A. ALMOEATHER

Educational Technology, Faculty of Education

Address: Princess Nourah Bint Abdulrahman Unversity, 11671, Riyadh, Saudi Arabia.

Phone: 00966504555154

E-mail: raalmoeather@pnu.edu.sa

\section{REFERENCES}

Abdelmonem, A. \& Naem, A. (2000). Utilization of multimedia technology in teaching physical sciences to basic education. Muscat, Oman: ALECSO.

Abdulatty, H. (2015). Performance support patterns and evaluating their impact on acquiring electronic evaluation skills by the faculty of Taif University using learning management system "Blackboard" and their attitudes towards them. Journal of Educational Sciences, 4, 231-250.

Abdulhameed, A. (2011). Impact of designing an e-learning strategy based on integrating online active learning and self-regulated learning skills on achievement and self-regulated e-learning strategies and developing reflective thinking skills. Journal of Mansoura Faculty of Education, 75(2), 249-316.

Abdulwahab, M. (2016). Effectiveness of collaborative learning based on utilizing the learning management system (Blackboard) in developing electronic design skills and retaining the impact of learning among the students of the College of Computers, Islamic University in Madinah. Journal of Education in Sohag, 46, 301-326.

Alhaqbany, K. (2017). What are the concept, principles and skills of self-regulated learning? Available at: https:// www.new-educ.com/

Aljanzoury, A. (2017). Faculty attitudes towards employing e-valuation tools using Blackboard in the educational process at Jouf University. Paper presented at Evaluation of University Education Symposium: Premises and Aspirations, College of Education, Jouf University.

Aljarrah, A. (2012). University of Jordan students' attitudes towards the use of Blackboard as a learning tool. Dirasat: Educational Sciences, 38(4), 1292-1304.

Aljarrah, A. (2010). Relationship between self-regulated learning and academic achievement in a sample of Yarmouk University students. Jordanian Journal of Educational Sciences, 4(6), 333-348.

Aljerewy, A. (2010). Evaluating the experience of Saudi universities in using learning management system (JUSUR) (Ph.D. dissertation). College of Education, Umm Al-Qura University, Mecca.

Al-Kathiri, F. (2015). Beyond the classroom walls: Edmodo in Saudi secondary school EFL instruction. Attitudes and Challenges English Language Teaching, 8(1), 189-204.

Almatrody, A. \& Alhassan, R. (2017). The effect of teaching using cooperative learning through educational social network Edmodo on the academic achievement in a computer course. International Journal for Research in Education, 41(4), 115-148.

Almoqren, N. (2016). Impact of e-learning using learning management system (Edmodo) on the achievement of the second secondary grade students in biology. International Interdisciplinary Journal of Education, 5(8), 217-246.

Alnajjar, J. (2010). Improving the quality of education using Blackboard (E-learning system). Journal of Basic Education, 66, 473-493. 
Al-Sadhan, A. (2015). Attitudes of the students and faculty members at the College of Computer and Sciences, Imam Muhammad ibn Saud Islamic University towards using learning management system Blackboard and its relation to some variables. Journal of Educational Sciences, 2, 223-278.

Al-Said, K. (2015). Students' perceptions of Edmodo and mobile learning and their real barriers towards them. Turkish Online Journal of Educational Technology, 2(14), 167-180.

Alsalloum, O \& Radwan, M. (2013). A proposed model for creating interactive courses according to learning management system "Blackboard" at King Saud University, Saudi Arabia. Journal of Arab Gulf Mission, 95, 108-129.

AlShaya, H. and AlHidari, Y. (2015). Effectiveness and satisfaction of an e-training program in the use of Blackboard for the faculty members at PNU. Journal of Educational and Psychological Sciences, 16(4), 371-407.

Alzahrany, N. \& Mejlad, E. (2018). Learning management system (Edmodo) for developing digital citizenship among the primary stage teachers in Mecca. Paper presented at the $18^{\text {th }}$ Conference of Saudi Association for Education \& Psychology "Post-Secondary Education: Identity and Development Requirements". Available at https://gesten.ksu.edu.sa/ar/node/1521.

American Library Association.(2011). Best websites for teaching and learning. Available at: http://www.ala. org/aasl/guidelinesandstandards/bestwebsitestep $25 \% 20 \#$ social

Badawy, M. (2011). E-learning and learning management systems: Blackboard as a learning management system. Electronic Education Magazine, 38, 7-39.

Bandura, A. (2002).Social cognitive theory in cultural context. Journal of Applied Psychology: An International Review, 51, 269-290.

Bernacki, M., Byrnes, J. \& Cromley, J. (2012). The effects of achievement goals and self-regulated learning behaviors on reading comprehension in technology-enhanced learning environments. Contemporary Educational Psychology, 37(2), 148-161.

Beverley, E. (2012). Using web 2.0 and social networking tools in the k-12 classroom. New York: Neal-Schuman Publishers.

Cigdem, H. (2015). How does self-regulation affect computer programming achievement in a blended context? Contemporary Educational Technology, 6(1), 19-37.

Chen, Y., Wang, Y., Kinshuk, N. \& Chen, N. (2014). Is FLIP enough? Or should we use the flipped model instead? Computer\& Education, 79, 16-27.

Cleary, T. \& Zimmerman, B. (2004).Self-regulation empowerment program: A school-based program to enhance self-regulated and self-motivated cycles of student learning. Psychology in the Schools, 41(5), 537-550.

Craf, S. \& List, B. (2005). An evaluation of open source e-learning platforms stressing adaptation issues. Paper presented at the Fifth IEEE International Conference on Advanced Learning Technologies, Kaohsiung, Taiwan.

Duru, E., Duru, S. \& Balkis, M. (2014). Analysis of relationships among burnout, academic achievement, and self-regulation. Educational Sciences: Theory \& Practice, 14(4), 1274-1284.

Grosseck, G. \& Holotescu, C. (2010). Microbologging multimedia-based teaching methods best practices with Cirip. eu. Procedia-Social and Behavioral Science, 2(2), 2151-2155.

Hassanein, E. (2011). Impact of training on employing some self-regulated strategies in the academic selfefficacy, test anxiety, and academic achievement among secondary stage students. Egyptian Journal for Psychological Studies, 21(73), 45-88.

Heirdsfield, A., Walker, S., Tambyah, M. \& Beutel, D. (2011). Blackboard as an online learning environment: What do teacher education students and staff think? Australian Journal of Teacher Education, 36(7), $1-17$. 
Jalal, A. \& Zaidieh, Y. (2012). The use of social networking in education: Challenges and opportunities. World of Computer Science and Information Technology Journal, 2(1), 18-21.

Kongchan, C. (2012). How a non-digital-native teacher makes use of Edmodo. Paper presented at the $5^{\text {th }}$ International Conference ICT for Language Learning, Florence, Italy.

Martin, F. (2008). Blackboard as the learning management system of a computer literacy course. Journal of Online Learning and Teaching, 4(2), 138-145.

Mazrou, Y., Abdulrahman, T., Makhlouf, A. (2013). Attitudes of the faculty of King Khalid University towards using the learning management system "Blackboard". Journal of the Educational Association of Social Studies, 84, 52-114.

Mohamed, H. (2017). Using the Edmodo platform for developing self-regulated learning skills and attitude towards employing it in teaching social studies for general diploma students at the Faculty of Education. Journal of Educational Association of Social Studies, 99, 90-139.

Moore, J. (2009). A synthesis of sloan -c effective practices. Journal of A Synchronous Learning Networks, 13(4), 73-97.

O'Leary, P. \& Quinlan, T. (2007). Learner-instructor telephone interaction: Effects on satisfaction and achievement of online students. The American Journal of Distance Education, 21(3), 133- 143.

Sanders, K. (2012). An examination of the academia networking site Edmodo on student engagement and responsible learning (Ph.D. dissertation). University of South Carolina, South Carolina, USA.

Sansone, C., Fraughton, T., Zachany, J., Butner, J. \& Heiner, C. (2011). Self-regulation of motivation when learning online: The importance of who, why and how. Educational Technology Research and Development, 59(2),199-212.

Sawaftah, A. (2016). Effectiveness of blended learning based on the learning management system Blackboard in developing attitudes toward physics for health colleges students at King Saud University. The Educational Journal, 30(119), 295-345.

Sayed, M. (2017). Using virtual classrooms to develop cognitive achievement and self-regulated learning skills for the first secondary grade students in history. Journal of Scientific Research in Education, $18,371-388$.

Schachter, R. (2011). Kid 2 kid connections: How to use technology to connect your student to a larger world. Instructor, 120(5), 46-52.

Schunk, D. \& Zimmerman, B. (2007). Influencing children's self-efficacy and self-regulation of reading and writing through modeling. Reading and Writing Quarterly, 23, 7-25.

Seyal, A., Ali, S., Awg, H., Yussof, H., Mohamad, H., Mohd, N....Rahman, M. (2010).Understanding students' attitudes toward e- learning: evidence from Bruneian vocational and technical education. Faculty of Business and Information Technology, Brunei.

Thongmak, M. (2013). Social network system in classrooms: Antecedents of Edmodo adoption. Journal of e-Learning and Higher Education, 2013. DOI: 10.5171/2013.657749.

Vrugt, A. \& Oort, F. (2008). Metacognition, achievement goals, study strategies and academic achievement: Pathways to achievement. Metacognition Learning, 30, 123-146.

Zhonggen, Y. \& Guifang, W. (2016). Academic achievements and satisfaction of the clicker-aided flipped business English writing class. Educational Technology \& Society, (19)2, 298-312. 